\title{
A framework of consumer perceived value on fashion products for female college students of France
}

YAN HONG

DOI: $10.35530 / I T .069 .06 .1408$

XIANYI ZENG

XUECHUN CAO

YU CHEN

YAN CHEN

ZHIJUAN PAN

\section{REZUMAT - ABSTRACT}

\section{Cadrul valoric perceput de consumator asupra articolelor de modă pentru studentele din Franța}

În ultimul timp, valoarea percepută de consumator este din ce în ce mai mult în atenția experților în marketing și branding. Cercetările actuale existente referitoare la valoarea percepută de consumator sunt lipsa de analiză a dimensiunilor interioare ale cadrului valoric perceput de consumator. In acest studiu, cercetarea noastră se concentrează asupra dezvoltării cadrului valoric perceput de consumator. Pentru a demonstra aplicarea cadrului propus, a fost dezvoltat un cadru valoric perceput de consumator pentru articolele de modă destinate studentelor din Franța. Pentru a obține cadrul dorit, o ipoteză bazată pe cunoaștere a fost inițial efectuată de un grup de manageri de marketing în domeniul modei pentru a genera un set de dimensiuni și indicatori corespunzători pentru valoarea percepută de consumator, care conține 4 dimensiuni și 26 de indicatori. Cadrul de ipoteze a fost validat și adaptat printr-un proces de analiză statică bazat pe rezultatele experimentale ale colectării datelor de la 350 de studente din Franța. În cele din urmă, a fost obținut un cadru valoric perceput de consumator pentru studente, care conține 7 dimensiuni și 26 de indicatori. Cadrul propus a fost validat printr-un set de analize. Rezultatele experimentale conexe au demonstrat că poate fi aplicat în continuare cadrul final pentru analiza comportamentală a consumatorului, strategia de marketing și planificarea design-ului noilor produse și dezvoltarea produsului.

Cuvinte-cheie: valoarea percepută de consumator, analiza comportamentală a consumatorului, modelare, ipoteză, proces bazat pe cunoaștere, structură ierarhică

\section{A framework of consumer perceived value on fashion products for female college students of France}

Consumer perceived value is paid attention by marketing and branding experts recently. Current existing researches related to consumer perceived value are lack of analysis of inner dimensions of the consumer perceived value framework. In this study, our research focuses on the development of the consumer perceived value framework. To demonstrate the application of the proposed framework, a fashion-based consumer perceived value framework for French female college students is developed. In order to obtain the desired framework, a knowledge-based conjecture is firstly performed by a group of professional fashion marketing managers to generate a set of dimensions and corresponding indicators of consumer perceived value, which contains 4 dimensions and 26 indicators. After that, the conjecture framework is validated and adapted through a process of statics analysis based on experimental results of collecting data from 350 female college students in France. Finally, we obtained a framework of consumer perceived value for French female college students, which contains 7 dimensions and 26 indicators. The proposed framework is validated though a set of analysis. Related experimental result has demonstrated that the final framework can be further applied to consumer behavior analysis, marketing strategy and new product design and development planning.

Keywords: consumer perceived value, consumer behaviour analysis, modelling, conjecture, knowledge-based process, and hierarchical structure

\section{INTRODUCTION}

Consumer perceived value is a concept related to marketing and branding strategy [1-2]. Based on the theory of consumer perceived value, the success of a product is largely relied on whether customers believe it can satisfy their needs [3]. Consumer perceived value emphasizes the importance of developing a market driven product development and marketing strategy, in which customers ultimately determine how to interpret and react to marketing messages [4-5]. Existing research on consumer perceived value focuses on services in purchasing such as tourism, shopping mall service, tourism, mobile shopping [6-7]. In this study, we focuses on the development of a framework of consumer perceived value on fashion purchasing.

The concept of consumer perceived value was put forward as a strategic imperative for producers and retailers in the 1990s [8]. Evolution of this concept has two phases. First, Zeithaml pointed out that consumer perceived value should be obtained from the comparisons between expectations and perceptions [9]. She has suggested that perceived value could be regarded as "consumer's overall assessment of the utility of a product (or service) based on perceptions of what is received and what is given" [10]. After that, Monroe put forward that consumer perceived value should be defined as the ratio or trade-off between 
quality and price, which is a value-for-money conceptualization [11]. Clearly, there are two dimensions involved in consumer perceived value: quality and price. Based on the definition of consumer perceived value, Woodruff have demonstrated that the framework of consumer perceived value follows a hierarchical structure [12], in which the consumer perceived value can be found on the root, dimensions of consumer perceived value are on the branches, and the indicators affecting these dimensions are on the leaves. These dimensions and indicators are independent to each other. However, existing studies on consumer perceived value are too general, especially about the content of the dimensions of consumer perceived value. More specific dimensions of consumer perceived value should be defined.

In this study, in order to overcome the current limitations of the consumer perceived value, we develop a new framework with a hierarchical structure, capable of defining the dimensions of consumer perceived value in fashion products purchasing. The rest of this study is organized as follows. In Section 2, the general framework of the proposed consumer perceived value is outlined. Two experiments are presented to explain how to define the dimensions of the proposed framework and their relative weights. Experiment subjects are female college students from France. Section 3 discusses the experiment results and provides suggestions for fashion brands. Section 4 concludes this paper.

\section{METHODOLOGY AND EXPERIMENTS}

Experiment I: Knowledge-based conjecture of the proposed consumer perceived value framework

The collection of the raw data has been carried out in two steps. A group of experienced fashion marketing managers have been invited for the identification of the dimensions of the proposed consumer perceived value framework (figure 1). The invited marketing managers have met the following three requirements: (1) he/she work in fashion marketing for more than 10 years; (2) the selected people are top managers or high-level managers in the company; (3) the selected people are specialists in consumer behavior analysis. Finally, 20 fashion-marketing managers were selected. Prior to data collection, a training section was carried out to avoid cognitive confusions and better understanding of the purpose of the research by the involved fashion-marketing managers. First, each of the invited fashion-marketing managers was asked to give in-depth interviews on an exhaustive list of the relevant dimensions of consumer perceived value framework for fashion, based on their professional knowledge and experience. The dimensions should satisfy the several requirements, including: (1) the selected dimensions must be the key of the consumer perceived value related to fashion; (2) only the quantifiable (measurable) dimensions can be selected; (3) the definition and the measurement method of these dimensions must be stable. Secondly, a screening was performed by a "round table" discussion among all the invited fashion-marketing managers, to select the most appropriate dimensions. Finally, a set of 4 dimensions was selected. Using the same method, 26 indicators were selected.

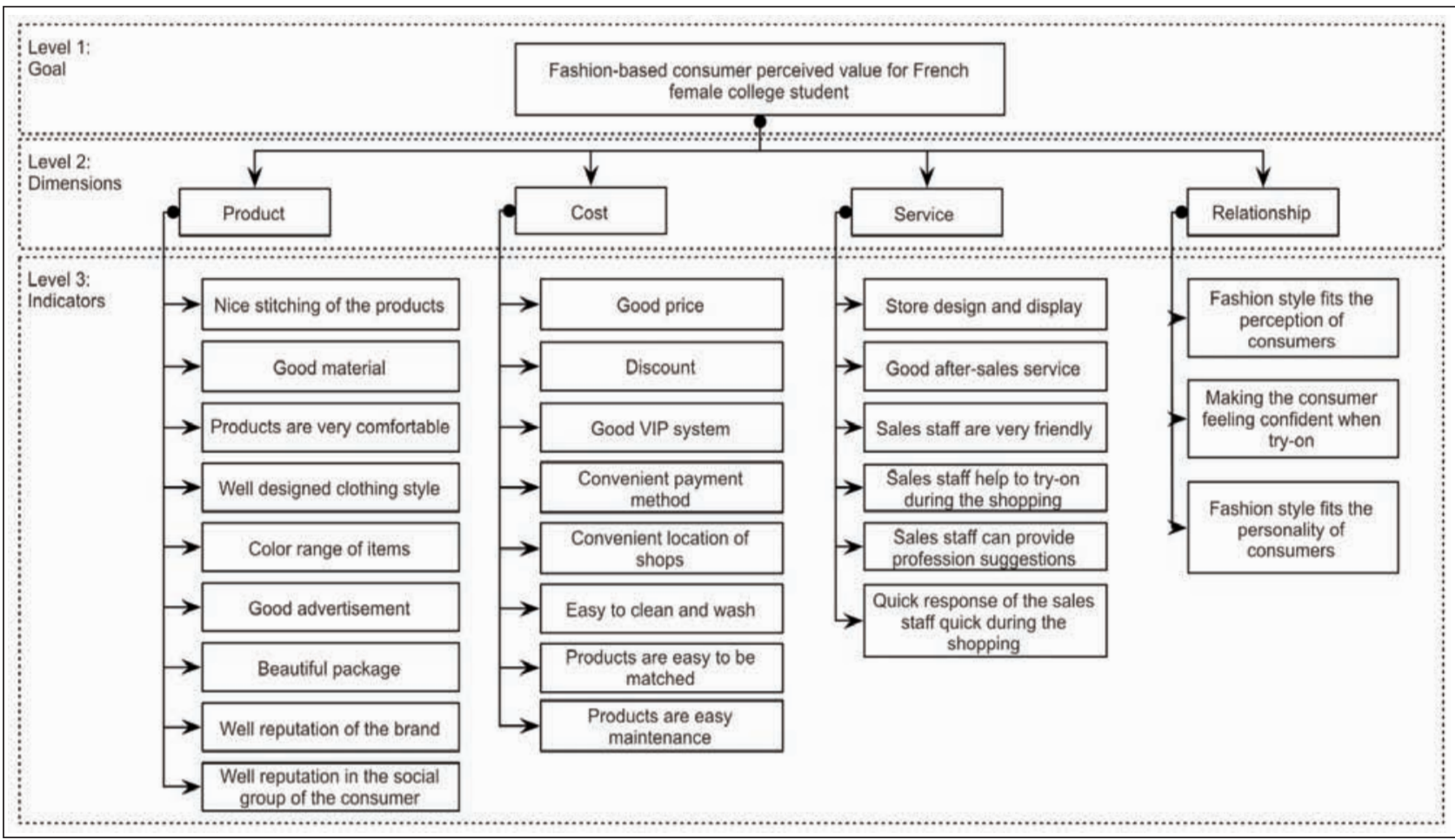

Fig. 1. Knowledge-based conjecture of the proposed consumer perceived value framework 
Experiment II: Demonstration and adaptation of the conjecture

In Experiment II, a questionnaire concerning the importance of the selected 26 indicators was released to 350 female college students from 15 different cities in France. The questionnaire was made from the 26 indicators and uses the SD method to describe each indicator. In order for the participants to answer in a more assertive way, an importance on a 5-point bipolar adjective scale with a neutral point at the middle (quite unimportant, slightly unimportant, normal, slightly important, quite important) was employed. Besides, education background, average monthly living expense and average monthly fashion expense were also collected in the questionnaire. After the survey, 325 (92.3\% of the whole 350 answers) proper answers were obtained.

\section{Verification of the selected indicators}

In order to verify if the selected 26 indicators are efficient, calculations of Common Factor Variance (CFV) were performed. Common Factor Variance has been verified for its potential in identifying if one indicator is relied on the common factor among all the indicators or not. If the CFV value of one certain indicator is too small, it should be considered to be an unreasonable indicator. Normally, the value of CFV of one indicator should be higher than 0.4. After the calculation of the CFV values, the whole 26 selected indicators are proved to be reasonable, which demonstrate the conjecture about the selection of 26 indicators is reasonable.

\section{Verification of the selected consumer perceived value dimensions}

In order to verify the selected value dimensions, Principal Component Analysis (PCA) was performed. PCA is a statistical procedure that uses an orthogonal transformation to convert a set of observations of possibly correlated variables into a set of values of linearly uncorrelated variables called principal components [13]. Since indicators of consumer perceived value has been verified, this section was designed to verify if principal components obtained from PCA will support the previous conjecture gained by experts based on their experience.

After the analysis, there are seven principles whose Initial Eigenvalue is greater than 1. It means there are seven principle components can be selected. Figure 2 presents the result of the PCA. From figure 2, we can find out that, the first principal components have the largest eigenvalue. From the second principal component to the seventh component, the value of eigenvalue reduces gradually. From the eighth principle component, the rest eigenvalues are rather small. In this condition, we define seven principle components based on the static analysis, which is different from the conjecture.

In order to validate the independence of the selected seven principle components, Component Score Covariance (CSC) of these principle components were analyzed [13]. Using CSC analysis, it found that

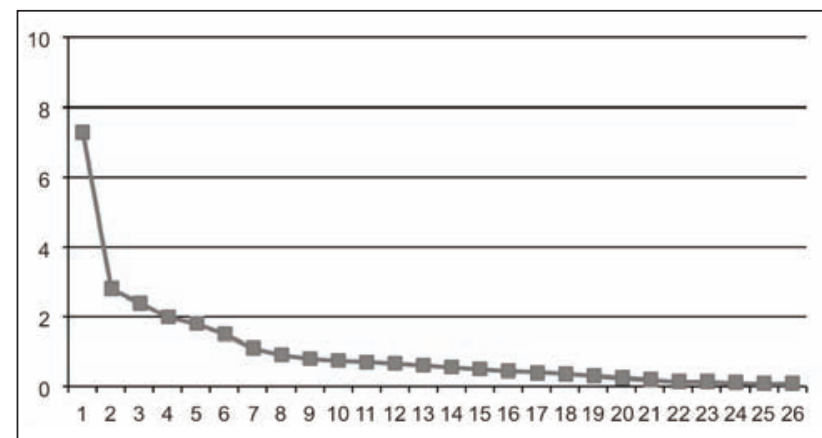

Fig. 2. PCA of the selected indicators

there is no linear correlation among the selected seven principle components. It can be concluded that all these principle components are independent. Let $F_{1}, F_{2}, F_{3}, F_{4}, F_{5}, F_{6}$ and $F_{7}$ be the new dimensions of the proposed consumer perceived value.

\section{Adaptation of the structure of the proposed framework}

Since the branch of the proposed hierarchical framework is modified, belongings of different indicators to different dimensions should be modified.

Table 1 presents Ingredient matrix composed of the capacity factor, which means the relationship between all the indicators and the selected principle components. When the value of one indicator on one certain principle component is higher, it means that this indicator is more greatly influenced by this principle component. For example, $F_{3}$ strongly influences the indicator "Good price", "Discount", "Store design and display", "Well reputation of the brand", "Well reputation in the social group of the consumer", "Good advertisement" and "Convenient payment method". However, $F_{4}$ also has impacts on "Discount", "Good VIP system", "Sales staff can provide profession suggestions", "Well reputation of the brand", "Fashion style fits the perception of consumers" and "Good price". One indicator can be greatly influenced by two or more principle components. In this situation, Maximum Variance Rotation Method was applied to solve this problem [14]. After that, the whole 26 indicators are distributed to the seven principle components. Based on the distribution of the indicators, it is possible to redefine the seven principle components, as presented in table 2.

$F_{1}$ refers to 8 indicators: "Convenient payment method", "Convenient location of shops", "Sales staff help to try-on during the shopping", "Sales staff can provide profession suggestions", "Beautiful package", "Quick response of the sales staff quick during the shopping", "Good after-sales service" and "Sales staff are very friendly". All of these indicators are related to the service provided in store. In this condition, $F_{1}$ is named as "Service". $F_{2}$ refers to 5 indicators: "Making the consumer feeling confident when try-on", "Fashion style fits the personality of consumers", "Color range of items", "Fashion style fits the perception of consumers", and "Well designed clothing style". All of these indicators are related to 


\begin{tabular}{|c|c|c|c|c|c|c|c|}
\hline \multirow[t]{2}{*}{ Selected indicators } & \multicolumn{7}{|c|}{$\begin{array}{l}\text { Capacity factor of each indicator on each } \\
\text { principle components }\end{array}$} \\
\hline & $F_{1}$ & $F_{2}$ & $F_{3}$ & $F_{4}$ & $F_{5}$ & $F_{6}$ & $F_{7}$ \\
\hline Good after-sales service & 0.70 & 0.02 & 0.00 & -0.14 & 0.04 & -0.16 & 0.09 \\
\hline $\begin{array}{l}\text { Quick response of the sales staff quick during the } \\
\text { shopping }\end{array}$ & 0.65 & -0.12 & 0.08 & -0.10 & 0.13 & -0.02 & 0.09 \\
\hline Products are easy to be matched & 0.64 & 0.01 & 0.00 & -0.12 & 0.18 & -0.16 & -0.54 \\
\hline Beautiful package & 0.62 & -0.39 & -0.19 & 0.15 & -0.25 & -0.16 & 0.18 \\
\hline Products are easy maintenance & 0.60 & -0.29 & -0.19 & -0.04 & 0.29 & -0.23 & -0.24 \\
\hline Sales staff help to try-on during the shopping & 0.60 & -0.42 & -0.63 & 0.04 & -0.30 & -0.05 & 0.14 \\
\hline Nice stitching of the products & 0.60 & 0.21 & -0.27 & -0.16 & 0.34 & -0.14 & 0.29 \\
\hline Convenient location of shops & 0.58 & -0.39 & 0.17 & -0.09 & -0.17 & -0.05 & -0.04 \\
\hline Fashion style fits the perception of consumers & 0.57 & 0.22 & 0.16 & -0.35 & -0.30 & 0.15 & -0.13 \\
\hline Good material & 0.57 & 0.27 & -0.24 & -0.04 & 0.31 & -0.15 & 0.26 \\
\hline Fashion style fits the personality of consumers & 0.56 & 0.31 & -0.04 & -0.08 & -0.42 & 0.17 & -0.15 \\
\hline Products are very comfortable & 0.55 & 0.25 & -0.23 & 0.06 & 0.41 & -0.14 & 0.06 \\
\hline Convenient payment method & 0.55 & -0.29 & 0.31 & -0.12 & -0.14 & -0.26 & 0.00 \\
\hline Making the consumer feeling confident when try-on & 0.54 & 0.54 & 0.06 & -0.10 & -0.23 & 0.20 & -0.12 \\
\hline Sales staff are very friendly & 0.53 & -0.04 & 0.21 & -0.27 & 0.17 & 0.10 & 0.08 \\
\hline Good VIP system & 0.51 & -0.14 & 0.13 & 0.51 & -0.09 & -0.24 & 0.07 \\
\hline Good advertisement & 0.51 & -0.44 & -0.32 & 0.24 & 0.03 & 0.39 & 0.02 \\
\hline Sales staff can provide profession suggestions & 0.46 & -0.22 & 0.33 & -0.40 & 0.03 & -0.04 & 0.21 \\
\hline Store design and display & 0.46 & -0.23 & -0.45 & 0.37 & -0.10 & 0.36 & 0.00 \\
\hline Color range of items & 0.51 & 0.58 & -0.15 & 0.11 & -0.13 & 0.10 & 0.09 \\
\hline Well designed clothing style & 0.42 & 0.54 & -0.22 & 0.06 & -0.23 & -0.07 & 0.20 \\
\hline Good price & 0.24 & 0.39 & 0.53 & 0.30 & 0.00 & -0.11 & -0.05 \\
\hline Discount & 0.27 & 0.17 & 0.49 & 0.64 & 0.04 & -0.20 & -0.02 \\
\hline Well reputation of the brand & 0.39 & 0.55 & 0.34 & 0.10 & 0.37 & 0.05 & 0.14 \\
\hline Well reputation in the social group of the consumer & 0.38 & -0.19 & 0.48 & 0.02 & 0.25 & 0.46 & 0.05 \\
\hline Easy to clean and wash & 0.54 & 0.35 & -0.22 & 0.09 & 0.17 & 0.05 & -0.57 \\
\hline
\end{tabular}

the emotional needs of the consumers. As this one doesn't exist in the conjecture, based on the context, $F_{2}$ is named as "Emotion need". $F_{3}$ refers to 3 indicators: "Nice stitching of the products", "Good material" and "Products are very comfortable". All of these indicators are related to the internal properties of the product. In this condition, $F_{3}$ is named as "Product internal properties". $F_{4}$ refers to 2 indicators: "Store design and display" and "Good advertisement". All of these indicators are related to the visual image of the brand. In this condition, $F_{4}$ is named as "Brand visual image". $F_{5}$ refers to 3 indicators: "Easy to clean and wash", "Products are easy maintenance" and "Products are easy to be matched". All of these indicators are related to if the products of the brand can save time and energy for the consumer. In this condition, $F_{5}$ is named as "Non-monetary costs". $F_{6}$ refers to 3 indicators: "Discount", "Good price" and "Good VIP system". All of these indicators are related to the price of products. In this condition, $F_{6}$ is named as "Price". $F_{7}$ refers to 2 indicators: "Well reputation of the brand" and "Well reputation in the social group of the consumer". All of these indicators are related to the reputation.

\section{RESULT DISCUSSIONS AND SUGGESTION}

\section{Result discussion}

The final seven principle components, namely the dimensions of the proposed consumer perceived value framework, extracted by factor analysis are service, emotion need, product internal attribute, brand visual image, non-monetary cost, price and brand reputation. After empirical research, compared with the conjecture model, the final obtained model are more precise in the dimension division. Then final model can be regarded as the extension of the conjecture model.

The dimension of "Service" has not been changed. The dimension of "Product" is refined into "Product internal attribute" and "Brand visual image". The dimension of "Relationship" has been changed to "Emotion need", which better reflects the relationship between consumer and product. The dimension of 


\begin{tabular}{|c|c|c|c|c|c|c|c|c|}
\hline \multirow{2}{*}{ Dimensions } & \multirow{2}{*}{ Selected indicators of consumer perceived value } & \multicolumn{7}{|c|}{$\begin{array}{l}\text { Capacity factor of each indicator on each } \\
\text { principle components }\end{array}$} \\
\hline & & $F_{1}$ & $F_{2}$ & $F_{3}$ & $F_{4}$ & $F_{5}$ & $F_{6}$ & $F_{7}$ \\
\hline \multirow{8}{*}{$F_{1}$ : Service } & Convenient payment method & 0.72 & & & & & & \\
\hline & Convenient location of shops & 0.68 & & & & & & \\
\hline & Sales staff help to try-on during the shopping & 0.66 & & & & & & \\
\hline & Sales staff can provide profession suggestions & 0.64 & & & & & & \\
\hline & Beautiful package & 0.61 & & & & & & \\
\hline & $\begin{array}{l}\text { Quick response of the sales staff quick during the } \\
\text { shopping }\end{array}$ & 0.55 & & & & & & \\
\hline & Good after-sales service & 0.50 & & & & & & \\
\hline & Sales staff are very friendly & 0.41 & & & & & & \\
\hline \multirow{5}{*}{$\begin{array}{l}F_{2}: \text { Emotion } \\
\text { need }\end{array}$} & Making the consumer feeling confident when try-on & & 0.78 & & & & & \\
\hline & Fashion style fits the personality of consumers & & 0.74 & & & & & \\
\hline & Color range of items & & 0.67 & & & & & \\
\hline & Fashion style fits the perception of consumers & & 0.64 & & & & & \\
\hline & Well designed clothing style & & 0.61 & & & & & \\
\hline \multirow{3}{*}{$\begin{array}{l}F_{3}: \text { Product } \\
\text { internal } \\
\text { properties }\end{array}$} & Nice stitching of the products & & & 0.79 & & & & \\
\hline & Good material & & & 0.76 & & & & \\
\hline & Products are very comfortable & & & 0.69 & & & & \\
\hline \multirow{2}{*}{$\begin{array}{l}F_{4}: \text { Brand } \\
\text { visual image }\end{array}$} & Good advertisement & & & & 0.82 & & & \\
\hline & Store design and display & & & & 0.78 & & & \\
\hline \multirow{3}{*}{$\begin{array}{l}F_{5}: \text { Non-mon- } \\
\text { etary costs }\end{array}$} & Easy to clean and wash & & & & & 0.77 & & \\
\hline & Products are easy to be matched & & & & & 0.74 & & \\
\hline & Products are easy maintenance & & & & & 0.57 & & \\
\hline \multirow{3}{*}{$F_{6}:$ Price } & Good price & & & & & & 0.87 & \\
\hline & Discount & & & & & & 0.65 & \\
\hline & Good VIP system & & & & & & 0.60 & \\
\hline \multirow{2}{*}{$\begin{array}{l}F_{7}: \text { Brand } \\
\text { reputation }\end{array}$} & Well reputation in the social group of the consumer & & & & & & & 0.78 \\
\hline & Well reputation of the brand & & & & & & & 0.74 \\
\hline Eigenvalues & & 7.4 & 2.5 & 1.8 & 1.5 & 1.4 & 1.2 & 1.1 \\
\hline $\begin{array}{l}\text { Explained } \\
\text { variance }\end{array}$ & & 14.2 & 11 & 10 & 8.7 & 7.2 & 6.8 & 6.7 \\
\hline $\begin{array}{l}\text { Cumulative } \\
\text { variance }\end{array}$ & & 14.2 & 25 & 35.2 & 44 & 51 & 58 & 64.6 \\
\hline
\end{tabular}

"Budget" is refined into "Price" and "Non-monetary costs". Although the results of empirical research and the conjecture are different, but they both grasp the same understanding customer perceived value. The result affirms that conjecture is reasonable.

\section{Suggestions to fashion brands}

Based on the hierarchical model of fashion-based consumer perceived value for female college students in France, this section puts forward the corresponding marketing strategy for fashion brands from the aspects of service, product and price.

\section{Service strategy}

"Service" is the most influential dimension of female college students on fashion-based consumer perceived value. Indicators related to "service" can be classified into two groups: one is related to the convenience of consumption, another is related to the sales staff. For the aspect of the convenience of consumption, fashion brands should try to provide products in a fast and convenient manner.

On the other hand, regarding the sales staff, a professional training of the sales staff should be carried out especially about the professional skill and manner in service. In this context, fashion brands should provide good services to improve their consumers' perceived value. For example, carefully select the location of shops and try-to provide $\mathrm{O} 2 \mathrm{O}$ service.

\section{Product strategy}

Based on the experiment data, "product" is also a dimension, which is very influential in consumer perceived value. In fashion marketing, "product" cannot be simply understood as "sell products". It refers to the product itself, but also has the extension of the promotion of the brand. Currently, French brands are strong in product design and development, but some 


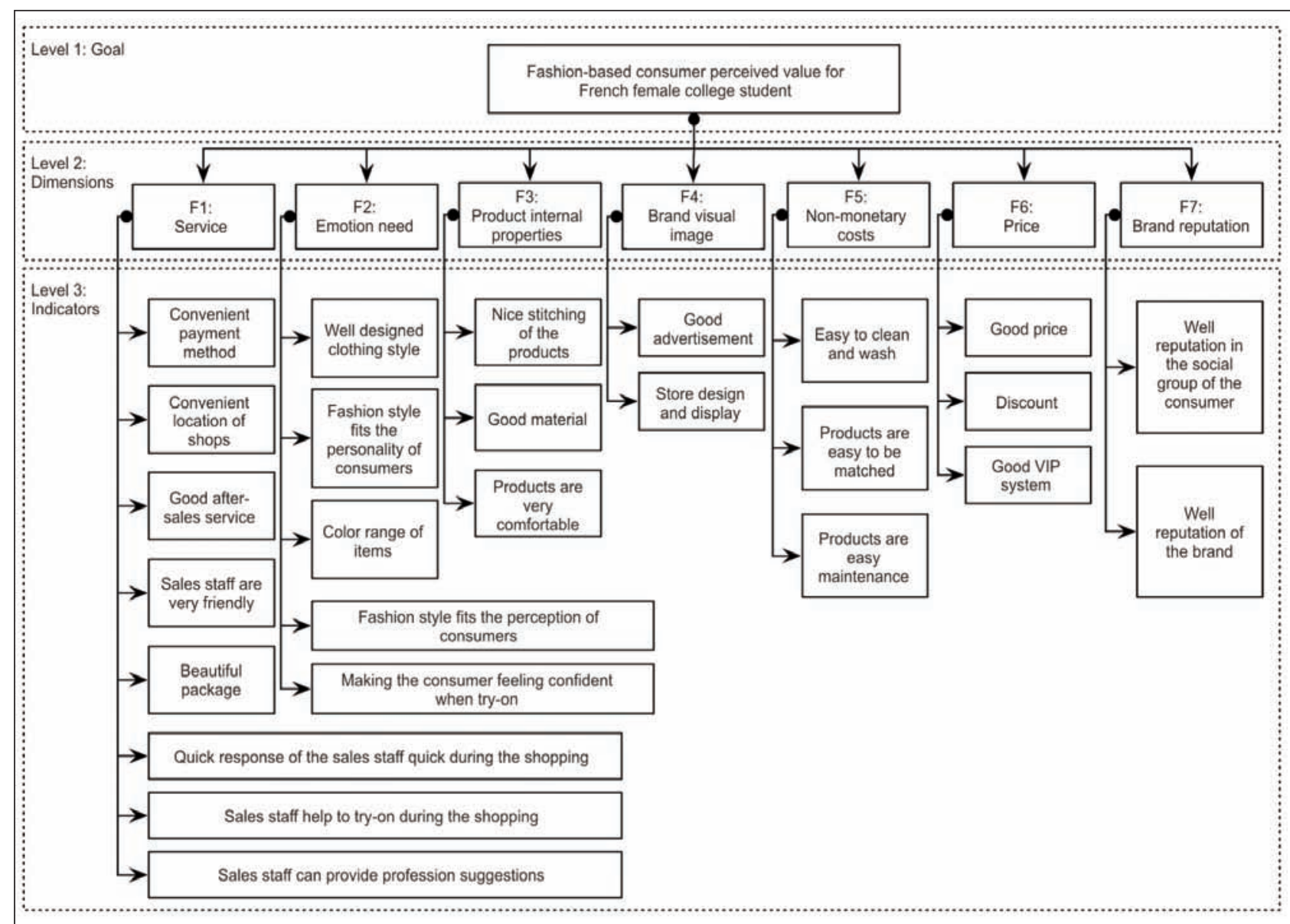

Fig. 3. Final consumer perceived value framework

of the local French brands have the problem of ambiguity of brand position and style. The relationship between "design" and "brand position" is not clearly verified. In this context, fashion brands should focus not only product development, but also built up good brand image. For example, seize the advantage of local culture, and promoting cultivates innovative design talents.

\section{Price strategy}

Due to the increasing competition, the market share of the female college students should be well captured by fashion brands. In the final obtained model, perceived value about "price" of female university students includes monetary cost and non-monetary cost. Different female university students' perceptions of non-monetary cost are different. At the same time, monetary cost becomes the main factor, which has a direct impact on the purchase decision of female college students. In this situation, developing a reasonable price range should be well considered by fashion brands. Discount promotion can also be considered.

\section{CONCLUSION}

This paper analyzes the framework of fashion-based customer perceived value of French female college students. The analysis begins with knowledge-based theoretical conjecture, realized by experts based on their professional knowledge and experience. The conjecture framework is then validated and modified by experimental results.

Finally, we obtained a framework of consumer perceived value for French female college students, which contains 7 dimensions and 26 indicators. The proposed framework can be future applied to consumer behavior analysis, marketing strategy and product development planning.

\section{Acknowledgements}

Thanks to the experts and students who participate in the survey.

\section{BIBLIOGRAPHY}

[1] Negoita, O., Ghituleasa C., Purcarea, A.A., Negoita, O. Branding Process - an important factor in guiding the company towards success, In: Industria textila, no. 2, 2015, pp. 103-107.

[2] Negoita, O., Purcarea, A.A., Negoita, O. Brand - an important company asset in front of crisis challenges, In: Proceedings of The 3rd Review of Management and Economic Engineering Management Conference "Management of Crisis or Crisis of Management, 15th - 17th, September, 2012, Cluj-Napoca, Romania. 
[3] Negoita, O.I., Purcarea, A.A., Negoita, O.D., \& Ghituleasa, C. The model of continuous improvement of branding process-the key towards an efficient communication within Romanian textile industry, In: Industria Textila, no. 6, 2016, pp. 420-427.

[4] Alexandru, P., Corina, P. Differences in the clothing brand perception depending on generation, In: Industria Textila, no. 42, 2016, pp. 260-264.

[5] Aaker, D.A. (1996), Building strong brands, The Free Press, New York.

[6] Aaker, D.A. (1991), Managing brand equity: capitalizing on the value of a brand name, The Free Press, New York.

[7] Pelau, C., Stamule, T. (2013), Analysis of the consumer's reasons and driving factors for buying, In: International Journal of Economic Practices and Theories.

[8] Solomon, M.R. (2009), Consumer behaviour: buying, having, and being, Prentice Hall.

[9] Zeithaml, V.A. (1988), Consumer perceptions of price, quality, and value: a means-end model and synthesis of evidence, In: The Journal of marketing.

[10] Parasuraman, A., Zeithaml, V.A., Berry, L.L. Servqual: A multiple-item scale for measuring consumer perc, In: Journal of retailing, no. 1, 1988, pp. 12-40.

[11] Dodds, W.B., \& Monroe, K.B. The effect of brand and price information on subjective product evaluations, In: NA-Advances in Consumer Research, no. 12, 1985, pp. 85-90.

[12] Woodruff, R.B. Customer value: the next source for competitive advantage, In: Journal of the academy of marketing science, no. 2, 1997, pp. 139-153.

[13] Chattopadhyay R., Guha A., Jayadeva, Performance of neural networks for predicting yarn properties using principal component analysis, In: Journal of Applied Polymer Science, 2004, vol. 91, pp. 1746-1751.

[14] Sonnerup, B.U., \& Scheible, M. (1998), Minimum and maximum variance analysis, In: Analysis methods for multispacecraft data.

\section{Authors:}

\section{YAN HONG ${ }^{1}$, XUECHUN CAO ${ }^{1}$, YAN CHEN ${ }^{1}$, XIANYI ZENG ${ }^{2}$, YU CHEN ${ }^{3}$, ZHIJUAN PAN ${ }^{1}$}

${ }^{1}$ Soochow University, College of Textile and Clothing Engineering, 215021 No. 1 Shizi Street, Suzhou, China ${ }^{2}$ GEMTEX, ENSAIT, 2 allée Louise et Victor Champier, 59056 Roubaix Cedex 1, France

${ }^{3}$ School of Fashion Engineering, Shanghai University of Engineering Science, Shanghai, China

\section{Corresponding author:}

\section{Prof. ZHIJUAN PAN}

e-mail: zhjpan@suda.edu.cn

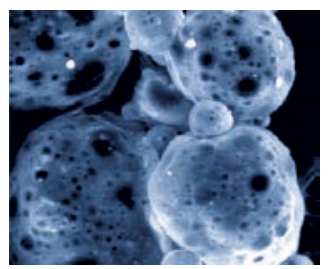

